\title{
Issues and Challenges of Student Financing Systems in Africa: The Case of Tanzania
}

\author{
Masumbuko Mathew Kossey and \\ Johnson Muchunguzi Ishengoma
}

\begin{abstract}
:
This article investigates the challenges confronting student financing systems in Africa, with specific reference to Tanzania's Higher Education Students' Loans Board (HESLB). It shows that the major challenges include limited resources, unemployment among loan beneficiaries, increased loans applications, the lack of a national identification system, emigration of loan beneficiaries, poor policy and legal frameworks, and corruption among HESLB staff and loan beneficiaries. The article recommends that the HESLB should diversify its sources of funding to reduce dependence on government; enforce loan repayment through legislation that enables direct reimbursement from beneficiaries' salaries; charge interest higher than the inflation rate; and embark on aggressive public education campaigns on the importance and benefits of the loan scheme and loan repayments.
\end{abstract}

Key words: Student financing system, challenge, student loans board/ scheme

Cet article examine les défis auxquels sont confrontés les systèmes de financement de l'enseignement supérieur en Afrique, en prenant pour exemple le Comité de Prêts pour Etudiants de l'Enseignement Supérieur de Tanzanie (HESLB). Il montre que les défis principaux sont liés au manque de ressources et au chômage des bénéficiaires de prêts, à une augmentation

Aвout the AUthors: MASUmbuko MATHEW KOSSEy Agency for the Development of Educational Management (ADEM) E-mail: kossey99@yahoo.com

JOHNSON MUCHUNGUZI ISHENGOMA University of Dar es Salaam, School of Education, Department of Educational Foundations, Management \& Lifelong Learning. E-mail: johnzi958@gmail.com 
des demandes de prêts, à l'absence d'un système d'identification national, à l'émigration des bénéficiaires de prêts, à l'inadaptation des politiques et des cadres légaux, et à la corruption du personnel de l'HESLB et des bénéficiaires de prêts. Cet article recommande que l'HESLB diversifie ses sources de financement pour limiter sa dépendance vis-à-vis du gouvernement ; qu'il renforce le taux de remboursement des prêts au moyen d'une législation permettant un prélèvement direct sur le salaire des bénéficiaires ; qu'il charge des intérêts plus haut que l'inflation; et qu'il mène une campagne agressive d'éducation du public sur l'importance et les bénéfices du système de prêts et de remboursements pour les étudiants.

\section{Introduction}

Student loans schemes have been established in about 70 countries around the world (World Bank, 20IO). In the wider framework of cost sharing, such schemes are becoming a major government strategy for student financing in both developed and developing countries. Woodhall (I99I) observed that by I99I, student loans schemes had been established in six sub-Saharan African countries (Ghana, Kenya, Lesotho, Malawi, Nigeria, and Zimbabwe), while Botswana, Tanzania, and Uganda were contemplating their introduction. The factors leading to the introduction of student loans schemes in African countries include the need to reduce public expenditure on higher education and shift its costs to the major beneficiaries; improve the quality of higher education to make it more competitive in the global labour market; and make higher education more equitable and accessible. While student loans schemes in Africa confront a plethora of challenges that affect their performance, if strategically and effectively managed, they remain a viable and sustainable system of student financing.

The Higher Education Students' Loans Board (HESLB) was established by Act No. 9 of 2004 in Tanzania, to manage government student loans. Its two main objectives are to assist financially needy students who secure admission to accredited higher education institutions in and outside the country, and to recover all loans disbursed since I994. The establishment of the HESLB is also in line with the National Higher Education Policy of I999, which, among other things, stipulated that cost sharing was essential in order to effectively finance higher education in Tanzania. This should be achieved through a revolving student loan scheme that provides financial assistance to needy students (URT, I999). The Government Student Loans Scheme (GSLS) operated as a unit in the Ministry of Science, Technology and Higher Education from 1993 to 2005 , when it was replaced by the HESLB. One of its major challenges was loan recovery and the lack of a legal framework. As a result, it did not recover any loans.

Since its establishment, the HESLB has issued loans to all students 
enrolled in public and private universities in Tanzania and to a few (from middle and upper class families) studying abroad. However, it is underfunded. By 30 June 2012 the HESLB had disbursed loans amounting to TZS I.I trillion (USDi.7 billion), to I68,353 students (Bangu, 20I2). However, loan recovery remains a major challenge, undermining its effective performance. Ally (20I5, p. I49) observes that, since its inception, the Board has confronted several challenges, including the continuous increase in the number of needy students; rising tuition fees; budget constraints; and negative public attitudes towards the scheme, possibly as a result of the HESLB's "soft repayment terms". Ally (ibid.) notes that repayment is set at 8 percent of gross salary (rather than basic salary), and is spread over ten years. There is a paucity of research on the challenges confronting the Board from stakeholders' perspectives. This study sought to fill this gap.

\section{Problem Statement}

The HESLB was established to address the problems inherent in the previous student financing scheme. However, the evidence shows that it has been underperforming due to a myriad challenges (Felix, 2009; Ndomba, 2009; Rugambuka, 2008). These include: complicated and time-consuming application procedures, delays in loan disbursements, double payments to a single student, unreliable and corrupt means testing and failure to recover loans. This article unpacks these challenges from stakeholders' perspectives. It seeks to answer the question: What are the challenges and issues facing the HESLB in student financing and how do these challenges constrain its performance?

\section{Challenges confronting Student Financing through Loans Schemes in Africa: Experiences from Kenya, South Africa, Uganda, Mauritius, and Rwanda}

Overall, the challenges confronting student financing through loan schemes in Africa can be categorized as follows: inadequate financial, human, and material resources resulting from underfunding; loan repayment and recovery, and administration and management.

\section{Resource Challenges}

The evidence (for example from Tanzania) shows that in many cases, governments do not allocate sufficient financial resources to enable loans schemes to meet their statutory obligation of issuing loans to needy students. The majority of schemes in Africa operate with lean budgets that cannot cover their operational costs and absorb the rising cost of higher education and expanded enrollments in many universities. Inadequate financial resources are largely due to dependence on government funding. 


\section{Challenges Related to Loan Recovery and Repayment}

Documentary evidence shows that almost all student loan schemes in Africa suffer low recovery and repayment rates. As Otieno (2004) argues, recovering student loans at full cost is a daunting task for many loans programmes in Africa. With some exceptions, these schemes have limited capacity (in terms of skilled human resources and state-of-the-art ICT) to track loan recipients. In some countries, loan repayments are derailed by the lack of a national identification system and recipients' misconceptions that student loans are government grants because higher education ought to be free. For example, a study by Ishengoma (2006) on students' attitudes towards cost sharing through loans revealed that they were unwilling to repay their loans from the HESLB because they considered higher education as a basic right which should be paid for by the government. This has led to subtle resistance to loan repayment in Tanzania.

\section{Challenges Related to Management and Administration}

Observation and documentary evidence show that top managers and administrators as well as employees of most student loans schemes are not professionals trained in disciplines relevant to student financing. For example, one of the longest serving top administrators of a student loans scheme in one of the countries mentioned above trained as a linguist. In Tanzania, the chief executive officer and chairperson of the board of directors of the HESLB are presidential appointees. This implies limited independent decision-making and vulnerability to political pressure and manipulation to make decisions that favour the establishment or the ruling party. While this is not to suggest that professional training in loans schemes management and related disciplines is a guarantee of efficient functioning, we believe that it is a sine qua non for any successful and sustainable student loans scheme worldwide.

\section{The Higher Education Student Loans Scheme in Kenya}

The first University Student Loans Scheme (USLS) in Kenya was introduced in 1974 in response to the declining state budget for public universities. It was established to enable needy students to access higher education. According to Owino (2003), the scheme was passionately resisted by students and parents. Such resistance has also been reported in Uganda, Nigeria, Botswana, Ghana and Tanzania, highlighting misconceptions of free higher education.

The USLS had a number of shortcomings which eventually led to its replacement by the Higher Loans Board (HELB). For example, its staff lacked skills in loans scheme management and loan recovery (Otieno, 2004) Furthermore, beneficiaries were not properly educated on repay- 
ment obligations and the benefits accruing from repayment. The USLS also lacked a legal framework and thus the status of a legal entity with a mandate to enforce loan recovery. As a department in the Ministry of Education, it had limited autonomy in terms of decision making.

In 1995 the government established the Higher Education Loans Board (HELB). It was charged with the responsibility of facilitating disbursement of loans, scholarships and bursaries to needy students, recovering all outstanding loans disbursed since I952 through the former Higher Education Loans Fund (HELF), and establishing a revolving fund from which funds could be drawn (Otieno, ibid.). Recovering outstanding loans proved a monumental challenge due to the lack of a database and records. The HELB extended its services to cover students enrolled in public and chartered private universities at all levels. While well-intentioned, this constitutes one of its major challenges because the Board is underfunded and largely depends on government for funding. However, documentary evidence shows that compared to other student loan schemes in the East African region, the HELB is performing much better in terms of loan recovery, apparently because there is a strong culture of repayment among loan recipients. This is due to the nation's long engagement with capitalism which inculcates personal responsibility for one's well-being, instead of shifting responsibility to the government.

Despite its relatively good performance in loan recovery, the HELB is not functioning optimally as a result of expanded student enrollment and its limited financial capacity as well as other challenges. Enrollment in state universities rose by 4I percent from I95,428 (20I2) to 276,349 in 2015 . Overall, student enrollment rose by about 35 percent from 240,55 in 20I2, to 324,560 in 2014 (Nganga, 20I4). The major challenge facing the HELB is inadequate budgetary allocations. For example, in 2013/14 the government allocated KES 2.365 billion, equivalent to I5 percent of the requested KES I4.5 billion (HELB, 20I3). The HELB's Strategic Plan 2013-2018 states that inadequate funding is one of its major challenges. Others include:

- over dependence on government funding

- incomplete student records, which frustrate loan recovery

- a weak regulatory framework, e.g., the cabinet minister in charge of education can override the decisions of the Board, and waive loans, loan penalties or interest on loans

- rising graduate unemployment, which may cause loan beneficiaries to seek employment outside the country and complicate loan recovery

- a weak loan compliance/inspection mechanism, and

- inadequate infrastructure and systems integration (HELB, op. cit. pp. 4-6).

Concerns have also been raised regarding equitable distribution of loans 
among applicants, a limitation which is related to overall loans management. Odebero et al.'s (2007) study revealed inequities along socioeconomic lines and between study programmes and recommended the development of a proper means testing tool to identify students most in need. In Tanzania, stakeholders have also raised concerns regarding inequitable distribution of loans by the HESLB.

\section{The Ugandan Experience}

While plans to establish a student loans scheme in Uganda can be traced back to the government White Paper of 1992, the country is a newcomer in student financing in the East African region. The White Paper recommended that a system be established to extend interest free loans to students who were unable to raise the funds required to finance their university education (Onen et al., 2013, p.274).

In 20I4, the government established the Higher Education Students Financing Board (HESFB) in terms of the Higher Education Financing Act No. 2. The Board provides loans and scholarships to all undergraduate students pursuing degrees in public and chartered private universities. Although it is too early to speculate, there are clear signs that the HESFB's operations are likely to be impeded by its dependence on government funding. Another potential challenge is that the interest rate on loans is determined by the Minister for Education and Sports in consultation with the Minister for Finance. This is vulnerable to abuse for political gain and influence. Other challenges could include resistance or unwillingness on the part of beneficiaries to repay loans, given the fact that, like Tanzanians, Ugandans have been used to 'free education' since independence.

\section{Higher Education Student Loans Schemes in Mauritius}

Mauritius has no history of government-managed student loans schemes, but has experience of government-guaranteed or government-backed schemes. In terms of these schemes, the government guarantees loans to students issued by commercial banks (the majority private) that charge commercial interest rates. Eleven banks are involved and other organisations and individual government ministries also manage student loans schemes. Their objectives and motives differ, but as Mohadeb (2006) observes, most have a profit motive (albeit disguised), manifested by high interest rates and imposition of the same loan conditions required by commercial banks for personal loans. In an attempt to establish a government managed student loans scheme, the government established the Human Resource, Knowledge and Arts Development Fund (HRK\&ADF) in 2008 under the auspices of the Ministry of Education and Human Resources. The HRKF \& ADF is also a government-guaranteed student loans scheme 
where commercial banks make loans available to all students admitted to recognised tertiary and higher education institutions (public and private) and charge commercial interest rates.

Although not well-documented in the literature, the numerous profitoriented student loans schemes currently operating in Mauritius are likely to exacerbate inequities in access to higher education. Available data show that more than 50 percent of students enrolled in public higher education institutions are from middle- and high-income groups (Mohadeb, 2010). Inequity is "reinforced by the fact that enrolment in public higher education institutions is based on the best school-leaving results which are more likely to be achieved by students from the best and most elite secondary schools" (Mohadeb, ibid., p. 93).

\section{Rwanda}

The Student Financing Agency for Rwanda (SFAR) was set up by the government in 2003 and established by law in 2006. The Agency is fully funded by the government. Due to its poor loan recovery performance, its functions were transferred to the Rwanda Education Board (REB) in 20II and to the Development Bank of Rwanda (BRD) in 20I5. Loan recovery has been a serious challenge to the SFAR due to the lack of viable loan recovery mechanisms. By 2015 , it had yet to recover approximately US\$ 98 million in loans disbursed since the I990s. Beneficiaries are expected to repay their loans within I5 years of gaining employment at an interest rate of II percent. However, this high interest rate is likely to cause further defaulting. The Auditor General's report of 2013/14 identified the weak legal framework to enforce loan repayment as another challenge confronting the SFAR. For example, the law establishing the SFAR did not specify clear sanctions or penalties that would be imposed if beneficiaries default or for employers who do not declare loan beneficiaries that they employ and enforce monthly deductions. The Report also pointed to the lack of a complete database to track loan beneficiaries.

\section{Student Loans Schemes in South Africa}

In South Africa, student loans are disbursed by the National Student Financial Aid Scheme (NSFAS) established under the NSFAS Act No. 56 of I999 to incorporate the Tertiary Education Fund of South Africa (TEFSA) which existed from I99I. Loans granted by NSFAS are needs-based and subject to a relative interest rate and repayment is income contingent (WangengeOuma, 20I2).

NSFAS' overall performance is hampered by a number of factors detailed in the NSFAS Ministerial Review Committee Report and NSFAS 2014/15 Annual Report. The challenges include: underfunding (NSFAS receives its major 
funding from the government), corruption in allocation of loans/bursaries leading to undeserving students securing bursaries, a lack of appropriate skills and competencies among some staff and inadequate management capacity. A major challenge which threatens NSFAS' survival is the low debt recovery rate. The Ministerial Review Committee Report observed that "the debt recovery rate is approximately 25 percent, the second lowest recovery rate among student financial aid schemes in the world" (p.75). Other challenges are inadequate physical infrastructure which limits its operations, and high student drop out and low graduation rates leading to high default rates (Department of Higher Education \& Training, 20I2).

\section{Methodology}

\section{Target Population}

The target population included continuing students in 2012/2013 at four universities: University of Dar-es-Salaam (UDSM), University of Dodoma (UDOM), St John's University of Tanzania (SJUT) and Tumaini University Makumira Dar es Salaam College (TUMADARCo). These universities were selected as representative of public and private universities. HESLB officials, parents of continuing students and graduates who are loans beneficiaries from Dar-es-Salaam and Dodoma and Deans of Students from the four universities participated in the study.

\section{Study Sample and Sampling Techniques}

Three sampling techniques were employed. Stratified random sampling was used to sample students from the four selected universities to ensure proportional representation. However, the universities were purposively sampled based on the criteria that two were public universities and the other two represented private universities. The selected universities enrolled a large number of students, about 39.5 percent of total enrollment in universities in Tanzania. Purposive sampling was also employed for respondents from the HESLB and university officials. Convenience sampling was applied to sample graduate loans beneficiaries and parents of university students.

To further ensure a representative sample, the researchers used Yamane's formula for calculating survey studies' sample sizes to calculate the required sample for this study:

$$
n=\frac{N}{1+N(e)^{2}}
$$

Where $\boldsymbol{n}$ is sample size, $\boldsymbol{N}$ is total target population and $\boldsymbol{e}$ is level of precision. 
A 95 percent confidence level and $\mathrm{P}=.05$ was used to sample undergraduate students, HESLB officials and Deans of Students, while a 90 percent confidence level and $\mathrm{P}=. \mathrm{OI}$ was used to sample graduates and parents.

Using Yamane's formula, the sample for this study consisted of 396 continuing undergraduate students from the four universities, 70 HESLB officials, Ioo graduate loans beneficiaries, Ioo parents with children in universities and four university officials. The total sample size was thus 466. The respondents' profiles are summarised in table I below.

Table 1. Study Respondents' Profiles

\begin{tabular}{|l|c|c|c|}
\hline Category of Respondents & Male & Female & Total \\
\hline Students & 180 & 120 & 301 \\
\hline Graduates & 32 & 33 & 65 \\
\hline Deans of Students & 3 & 1 & 4 \\
\hline HESLB Officials & 24 & 15 & 39 \\
\hline Parents & 25 & 33 & 58 \\
\hline Grand Total & 264 & 202 & 466 \\
\hline
\end{tabular}

Of the 466 respondents, nine (five HESLB directors and four Deans of Students) were interviewed, while a questionnaire was administered to 458 respondents (366 students, 58 parents, and 34 HESLB officials).

\section{Data Collection Methods}

Data were collected through interviews, questionnaires, documentary review and focus group discussions (FGDs).

\section{Interviews}

Semi-structured interviews were conducted with key informants among HESLB officials and university administrators. The HESLB Executive Director and Directors of Finance and Administration, Planning, Research and ICT, Loans Repayment and Recovery and Loans Allocations and Disbursements were interviewed to determine the challenges confronting the HESLB and how these affected its performance. A Dean of Students from each of the selected universities was interviewed are they are in frequent communication with the HESLB to ensure that loans are disbursed on time and also handle other loans related problems, such as student strikes.

\section{Documentary review}

Documents reviewed included: policy documents and guidelines on the 
HESLB's establishment and operations, and HESLB annual reports that revealed the Board's financial status in terms of loans disbursement and recovery. HESLB strategic plans were also reviewed to establish its future plans and strategies.

\section{Questionnaires}

Questionnaires with open- and closed-ended questions were administered to gather qualitative and quantitative data on the challenges confronting the HESLB and their effects on its performance. The researchers administered questionnaires to undergraduate and graduate student loans beneficiaries.

\section{Focus group discussions}

Two FGDs comprised of six students were conducted at SJUT. The use of FGDs was informed by the need to capture conflicting views among HESLB loans beneficiaries from private universities that are considered to have more positive attitudes towards the loans scheme than students in public universities. The FGDs focussed on students' understanding of their legal obligations in terms of loan repayment, their perceptions of the challenges encountered by the HESLB and their views on improved strategies for student financing in Tanzania.

\section{Limitations of the Study}

The study depended on the respondents' willingness to divulge their personal views and perceptions. Thus, it was difficult to overcome bias due to negative attitudes and resistance to the student loans scheme. Some key respondents such as university and HESLB officials were reluctant to provide data, apparently because cost sharing through HESLB is considered a sensitive policy which has generated fierce public debate, especially among those opposed to it, for example, politicians who oppose it for political gain. Some data and records could not be accessed because of apparently poor record keeping at the HESLB.

\section{Findings and Discussion}

\section{Challenges Facing the HESLB in Student Financing}

The findings revealed the following major challenges encountered by the HESLB: limited financial, human, physical, and technological resources, the growing number of loans applicants, the lack of a national identification system, poor policy and legal frameworks, and emigration or unemployment of loan beneficiaries. Other challenges were corruption among HESLB staff, lack of cooperation from employers, rising tuition fees and misconceptions of loans as grants among loan beneficiaries. Table 2 below summarises the findings. 
Forty-three percent of the respondents identified limited resources as the major challenge constraining the HELB's performance. This was followed by unemployment among graduates ( 22 percent); the lack of a national identification system and the increasing number of loan applicants (I3 percent), emigration of loan beneficiaries (9 percent), other constraints ( 8 percent) and a poor policy framework ( 7 percent). Other constraints identified by the respondents include political pressure on the Board's management to make unfeasible decisions, corruption among HESLB officials, lack of cooperation from employers, rising tuition fees (particularly in private universities), and loans beneficiaries' misconceptions of loans as grants. Surprisingly, although the low rate of loan recoveries has been identified as a major challenge confronting many student loans schemes in Africa, this was not cited as a challenge, probably because the respondents were part and parcel of the problem.

Table 2. Challenges of Student Financing through HESLB

$\mathrm{N}=463$

\begin{tabular}{|c|c|c|c|c|c|c|}
\hline \multirow[b]{2}{*}{ Challenge } & \multicolumn{4}{|c|}{ Frequency } & \multirow[b]{2}{*}{ Total } & \multirow[b]{2}{*}{$\begin{array}{l}\text { Percentage } \\
\text { of } \\
\text { Responses }\end{array}$} \\
\hline & $\begin{array}{l}\text { HESLB } \\
\text { staff }\end{array}$ & Graduates & Students & Parents & & \\
\hline Limited resources & 30 & 31 & 104 & 34 & 199 & 43 \\
\hline Lack of national IDs & 15 & o & 43 & o & 58 & 13 \\
\hline $\begin{array}{l}\text { Emigration of loan } \\
\text { beneficiaries }\end{array}$ & 9 & 19 & 5 & 10 & 43 & 9 \\
\hline $\begin{array}{l}\text { Increasing number of } \\
\text { loans applicants }\end{array}$ & 27 & 4 & 26 & 2 & 59 & 13 \\
\hline $\begin{array}{l}\text { Poor policy } \\
\text { framework }\end{array}$ & 24 & O & o & 6 & 30 & 7 \\
\hline $\begin{array}{l}\text { Unemployment } \\
\text { among loan } \\
\text { beneficiaries }\end{array}$ & 22 & 3 & 78 & O & 103 & 22 \\
\hline Other challenges & o & o & 30 & 6 & 36 & 8 \\
\hline Total & 39 & 65 & 301 & 58 & 463 & \\
\hline
\end{tabular}


Limited financial resources: Limited financial resources were identified as the most critical challenge, leading to inadequacy of other resources. A member of the Board's management observed:

The funds we receive from the government do not match with the number of applicants. The number of applicants is always high, but the funding level is low to match with the increasing number of students applying for loans every year (HESLB Director A, I4/05/2013).

The HESLB's strategic plan for 20II-20I4 also indicates that it is underfunded in terms of loans disbursements, but not for operational activities. HESLB respondents further pointed out that the majority of qualified applicants miss out on loans due to inadequate funding. Table 3 below shows the differences between government subventions and HESLB budget requests since its establishment.

Table 3. HESLB budget requirements and government allocations: $2005 / 2006-2012 / 2013$

\begin{tabular}{|c|c|c|c|c|c|}
\hline \multirow{2}{*}{ Year } & \multicolumn{2}{|c|}{ HESLB Request } & \multicolumn{2}{c|}{ Government Allocation } & $\begin{array}{c}\text { Deficit } \\
\text { percentage }\end{array}$ \\
\hline & TZS(Bill) & USD(mill) & TZS (Bill) & USD(mill) & \\
\hline $2005 / 2006$ & 56.11 & 111.9 & 31.60 & 63.0 & 44 \\
\hline $2006 / 2007$ & 76.19 & 146.1 & 59.25 & 113.6 & 22 \\
\hline $2007 / 2008$ & 162.03 & 229.3 & 127.00 & 211.2 & 22 \\
\hline $2008 / 2009$ & 140.29 & 227.9 & 137.00 & 193.6 & 2 \\
\hline $2009 / 2010$ & 197.34 & 316.5 & 197.34 & 316.5 & 0 \\
\hline $2010 / 2011$ & 252.97 & 388.4 & 237.80 & 365.1 & 6 \\
\hline $2011 / 2012$ & 386.44 & 558.4 & 317.79 & 459.2 & 18 \\
\hline $2012 / 2013$ & 368.87 & 501.7 & 326.00 & 443.4 & 12 \\
\hline
\end{tabular}

Source: Field Survey, 2013

The HESLB's annual reports show that it has secondary sources of funding from interest on banks deposits, service charges and loan repayments, but these funds are used to cover personal emoluments, which are hefty, according to the recent audit report. As shown in figure $\mathrm{I}$, in the 20I2/20I3 HESLB budget, other sources of funds (apart from loan repayments/recovery) contributed 7 percent of its total budget. Loans recovery contributed only 5 percent, yet this is an important source which could guarantee the Board's financial sustainability and revolving status. 
Table 4. HESLB Sources of Income, 2012/2013 (\%)

\begin{tabular}{|l|c|}
\hline Source & Percentage (\%) \\
\hline Government subventions & 93 \\
\hline Loan repayments & 5 \\
\hline Service charges & 1 \\
\hline Interest from bank deposits & 1 \\
\hline Total & 100 \\
\hline
\end{tabular}

Source: HESLB (2013). Annual Report 2013

There is an urgent need for the HESLB to invite other partners such as banks and social security funds to support its efforts to provide student financing. This strategy has worked in Mauritius (Mohadeb, 2006) and for Kenya's HELB.

Human resources are critical in the efficient functioning of any organisation. Sixty-two percent of the HESLB staff that participated in the study pointed to staff shortages as a serious problem, particularly in the loans disbursement and recovery divisions. A director in one of these critical divisions observed:

Shortage of staff is a serious challenge in our department. We have few staffs in this department. Sometimes we do ask other members of staff from other departments to assist us. We plan to employ more staff. A total of 32 staffs are required in this department, but only I5 staffs are available (Director B, HESLB: 20/05/2013).

No specific information was available on HESLB staff's professional and academic qualifications. However, judging from the manner in which the Board's staff has mismanaged loan applications and disbursements, it can safely be speculated that, like other student financing agencies in Africa, the HESLB lacks professionally trained staff.

Shortage of physical facilities: The HESLB is constrained by limited office space because (by design or accident) it operates from rented premises with exorbitant monthly rent. There are only a few small offices and staff efficiency is reduced as they are forced to share offices. NSFAS in South Africa also suffers a lack of physical facilities.

Poor management of information systems: This is manifested by the fact that some graduate loans beneficiaries claimed that they had been allocated higher debt than what they were loaned, while others did not take loans at all, but found themselves indebted to the HESLB. This suggests problems 
with management of the information system which relates to the quality of the technology and programmes used as well as the qualifications of the staff managing these systems. Poor management of information is also noted as a challenge to Rwanda's SFAR.

\section{Graduate unemployment and low salaries}

University students who had taken loans were worried that they might find it hard to find employment after graduation and would hence be unable to repay their loans. Twenty-two percent of the respondents cited lack of employment as one of the factors constraining the HESLB's performance. Asked if they would start repaying their loans a year after completing their studies as per the HESLB loan agreement, I92 (63.5 percent) of the continuing student respondents stated that they would be unable to do so, citing graduate unemployment as the main reason. HESLB management also cited graduate unemployment and the low salaries paid to graduates as a challenge to loan repayment. A member of the HESLB management observed:

Graduate employment in the formal sector is a serious constraint to loans recovery. Also, inadequate salaries among graduate employees who are loan beneficiaries is another hindrance to loans repayment. Low salaries make it difficult to recover loans in a short period of time. We want loans to be recovered immediately after graduation, but you find one was loaned TZS Io million but his/her salary is below $400,000 /=$ TZS per month, and the country's labour laws do not allow us to deduct above one third of one's monthly salary. In this case, other loan beneficiaries take more than Io years repaying their loans (HESLB Director B, 20/05/2013).

This director added that it is difficult to trace unemployed and selfemployed graduates and those working in the informal sector.

While data is not available on graduate unemployment in Tanzania, according to the National Bureau of Statistics (2013), the country's unemployment rate is only II percent.

Lack of a national identification system: Board representatives also identified the lack of national identification cards as an impediment to loan recovery as it is very difficult to track loan beneficiaries.

The respondent in charge of loan recovery also observed that it would be easier to track loan beneficiaries if they applied for loans using national ID numbers. National IDs have been very instrumental in helping Kenya's HELB to recover loans and trace loan defaulters in partnership with the Kenya Revenue Authority. In Ghana, the Social Security and National 
Insurance Trust (SSNIT) assigns identification numbers to loan applicants; this has enabled the Student Loans Trust Fund (SLTF) to recover loans. However, in Tanzania, the issuing of national IDs has been mired in corruption, leading to the sacking of senior officials and the retrenchment of about 500 employees at the National Identification Authority (NIDA).

The increasing number of loan applicants: Although the Board does not provide data on the number of loan applicants (possibly for political reasons), the number of loans applicants has increased since its establishment (judging from the increasing number of loans beneficiaries in both public and private universities); while budgetary allocations from the government have not kept pace (see figure I below).

Figure 1. Number of HESLB Loan Beneficiaries: 2005/2006 to 2012/2013

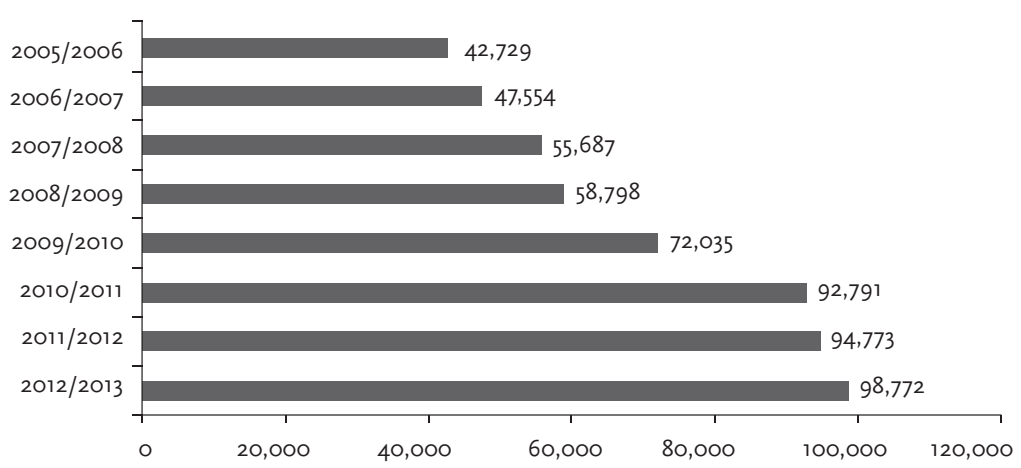

Source: HESLB Annual reports, 2006, 2007, 2008, 2009, 2010, 2011. 2012 Q 2013

The number of loans beneficiaries increased at an annual rate of I3 percent. The Board does not keep data on the number of loans applicants and the percentage receiving loans, although such data is very important in determining its financial capacity and performance. Thus, neither the level of need nor the HESLB's capacity to serve Tanzanian higher education students can be computed.

Emigration ofloans beneficiaries: Emigration of loans beneficiaries was also cited as a challenge, accounting for 9 percent of the total responses. A member of management observed:

A number of loans beneficiaries travel abroad and others are employed abroad, but they do not give us information of their whereabouts. But now, the list of loans beneficiaries has been 
submitted to the Ministry of Foreign Affairs and International Cooperation and therefore now loan beneficiaries cannot go abroad without making arrangements with HESLB on how to repay loans (HESLB Management Board Member C, 20/05/2013).

Although sections I9 (3) and 22 (2) c of the HESLB Act of 2004 provide for sanctions for defaulting beneficiaries that reside overseas or are pursuing further studies abroad, none have thus far been punished. The above claims by the HESLB representative are not supported by any evidence. At present, there is no working relationship between the Ministry and the Board. Furthermore, foreign embassies issuing visas to Tanzanians travelling abroad do not seek authorisation from the Ministry of Foreign Affairs and International Cooperation or from the HESLB. Emigration of loan beneficiaries has been reported as a challenge to Kenya's HELB and Ghana's SLTF (Otieno, 2004; Atuahene, 2008; Collins, 20I3).

Poor policy and legal frameworks: The interviews with HESLB Management Board members revealed some weaknesses in policies and policy frameworks, particularly in relation to loan repayments:

HESLB's policy weaknesses are related to loans repayment such as: a long amortization period, unnecessary one year grace period, and failure to make loans deductions mandatory by employers. Our laws are not very much binding to employers like that of Tanzania Revenue Authority (TRA) directing employers to deduct pay as you earn on employees' monthly salaries or and other social security funds requiring employers to deduct monthly contributions from members' salaries (HESLB Management Board Member D : 20/05/2013).

Apart from HESLB management board members, 56 percent of the other HESLB staff members that participated in the study were dissatisfied with the policies that guide HESLB operations. They argued that policy weaknesses have resulted in ineffective loan recovery. For example, section I9 (5) of the HESLB Act No. I7 of 2007 stipulates that the grace period for loan beneficiaries to start repayment is one year after graduation. However, respondents observed that not every loan beneficiary needs a one year's grace to raise income for loan repayment.

Another policy weakness is associated with the mandate of the minister in charge of the education portfolio to exempt some loan beneficiaries from repayment. Section 29 (2) of the HESLB Act of 2004 states that, through a notice in the Government Gazette, the minister in charge of education may: "exempt any class of persons from all or any of the provisions of this Act, where in his/her opinion it is in the public interest to do so" (p.20). This opens loopholes for abuse because cabinet ministers in 
Tanzania wield enormous power that sometimes goes unchecked. The concept of public interest is also liable to deliberate misinterpretation by unscrupulous politicians. Empirical evidence supports this observation. For example, Ishengoma's (2004) study revealed that sons and daughters of politicians and economically affluent Tanzanians were receiving loans to study at the University of Dar es Salaam through memos from politicians. A strong policy framework is a critical requirement for the success of any student loans scheme.

\section{Other Challenges}

Further challenges include corruption among HESLB staff, a lack of cooperation from employers, increases in tuition fees at private universities, misconceptions of loans as grants and graduate unemployment. Corruption among HESLB staff was mainly cited by students (continuing and graduates). During the interviews, some HESLB staff also admitted that there were cases before the courts involving corruption on the part of HESLB staff. This takes the form of embezzlement of funds, double loan allocations, ghost loan beneficiaries, disbursing loans to undeserving students, and contracting suspicious loans recovery agents. In 2016 , the government ordered a special audit of the Board's accounts which revealed massive embezzlement of TZS 3.2 billion (equivalent to US\$I,476, oI 4 million). The Prevention and Combating of Corruption Bureau has been charged with the investigation (Athumani, 2016). Corruption in allocation of loans and bursaries has also been cited as one of the critical challenges facing South Africa's NSFAS.

\section{Lack of Cooperation from Employers and Increases in Tuition Fees at Private Universities}

Members of HESLB management noted that lack of cooperation from employers of loans beneficiaries and frequent increases in tuition fees at private universities constrained the Board's effective functioning. Generally, employers did not comply with the legal provisions requiring them to make monthly deductions from the salaries of loans beneficiaries, while some deducted payments but did not remit them to the Board, despite the HESLB Act of 2004 requiring them to do so.

Respondents associated lack of cooperation from employers with the Board's poor legal framework, pointing out that no employer had been punished for non-compliance since the Board's inception. Ally (2015) observes that the HESLB's legal framework "was written without clear objectives and interrelationships between all implementers and strategic partners" (p.150).

Increases in tuition fees at private universities were identified as a 
further problem in terms of the Board's budget estimates. All private universities in Tanzania are essentially for-profit (albeit in disguise) and mainly rely on tuition fees to finance their operations (Ishengoma, 2008). This is illustrated by their 'passion' to launch new degree programmes in the HESB's priority disciplines even when they do not have the human resource capacity to offer them. Some were charging tuition fees in US\$ for both Tanzanians and non-Tanzanian students which could not be budgeted for by the Board, a malpractice which has been outlawed by the government. Fortunately, the government has developed a standard student unit cost for all public and private universities which is used to calculate tuition fees.

\section{Misconceptions of Loans as Government Grants}

As noted earlier, the majority of loans beneficiaries in Tanzania perceive loans as government grants (see for example Ishengoma, 2006). The Board will continue suffering poor loan recovery unless deliberate efforts are made to sensitize and educate the public on the importance and benefits of loan repayments. Aggressive information and education campaigns on such benefits conducted by Ghana's Student Loans Trust Fund have been very successful, culminating in voluntary loan repayments (Collins, 20I3).

\section{Potential Impact of the Challenges on the HESLB's Performance}

This study also solicited stakeholders' perspectives on the potential impact of the HESLB's challenges on its overall performance. Those identified included: dissatisfaction with the loan amount ( 42 percent), inadequate funding ( 39 percent), delays in loans disbursement (30 percent), low rate of loan recoveries ( $\mathrm{I} 8$ percent) and the diminishing value of loans recovered (see table 5). 
Table 5. Potential impact of challenges on HESLB's performance

\begin{tabular}{|c|c|c|c|c|c|c|}
\hline \multirow[t]{2}{*}{ Influence } & \multicolumn{4}{|c|}{ Frequency } & \multirow[b]{2}{*}{$\begin{array}{l}\text { Total No. } \\
\text { of respond- } \\
\text { ents }\end{array}$} & \multirow[b]{2}{*}{$\begin{array}{l}\text { Percentage } \\
\text { of } \\
\text { responses }\end{array}$} \\
\hline & $\begin{array}{l}\text { HESLB } \\
\text { staff }\end{array}$ & Graduates & Students & Parents & & \\
\hline $\begin{array}{l}\text { Dissatisfaction } \\
\text { with loan amount }\end{array}$ & 9 & 31 & 110 & 42 & 192 & 42 \\
\hline $\begin{array}{l}\text { Inadequate } \\
\text { funding }\end{array}$ & 3 & 23 & 132 & 20 & 178 & 39 \\
\hline $\begin{array}{l}\text { Delays in loans } \\
\text { disbursement }\end{array}$ & 6 & 36 & 70 & 26 & 138 & 30 \\
\hline $\begin{array}{l}\text { Low rate of loan } \\
\text { recovery }\end{array}$ & 9 & 26 & 31 & 18 & 84 & 18 \\
\hline $\begin{array}{l}\text { Diminishing value } \\
\text { of recovered loans }\end{array}$ & 6 & 17 & 32 & $\mathrm{O}$ & 55 & 12 \\
\hline Grand Total & 39 & 65 & 301 & 58 & 463 & \\
\hline
\end{tabular}

Source: Field Survey, 2013

\section{Dissatisfaction with loan amount for tuition fees}

Of the 30I student respondents, 233 (78 percent) were not satisfied with the loan amount they received from the Board. They claimed that HESLB means testing was flawed and that as a result of corruption among HESLB staff, students from upper and middle class families received large loans while those from poor families received less or missed out on loans. Dissatisfaction has implications for loan repayment.

However, students' claims of unfair allocations may be subjective because the process is computerized based on the information provided by applicants on the application form. Observations and records from the Board show that some students and their parents fabricate information to secure loans even when they do not qualify according to the set criteria, at times without the knowledge of HESLB officials. In Kenya, providing false information about one's socioeconomic status has been addressed by involving local leaders to identify needy students.

Delays in loan disbursement: Eighty-six percent of the student respondents reported that they did not receive loans on time. In extreme cases, some students did not receive their loans for a whole semester. HESLB officials admitted that there had been delays in loan disbursements because the government does not release requested funds to the Board on time. Fur- 
thermore, in many cases the Board receives less than what it requested and has to recast its budget to accommodate deficits. Loans are sometimes delayed due to universities' late submission of students' examinations results as these are used to allocate loans to continuing students (HESLB, 2013).

Low rate of loan recovery: The interviews with HESLB officials and documentary review suggest that the Board has not made significant progress in recovering loans. In June 2013 , the average cumulative recovery rate vis-à-vis due loans was 3.7 percent. Table 6 shows the amount of due loans and that recovered from 2007/2008 to April 2013.

To improve loan recovery, the Board has recruited debt collecting companies since $2008 / 2009$. However, a recent special audit revealed that some are not professional debt collection agencies. The performance of debt collecting companies contracted by the Board has been low at an average 3I.5 percent by 2013 .

Table 6. HESLB Loan Recovery Trends: $2007 / 2008$ to 2012/2013

\begin{tabular}{|c|c|c|c|c|c|c|c|c|}
\hline \multirow[t]{2}{*}{ Year } & \multicolumn{2}{|c|}{$\begin{array}{l}\text { Due loans for } \\
\text { repayment }\end{array}$} & \multicolumn{2}{|c|}{$\begin{array}{l}\text { Collection } \\
\text { Target }\end{array}$} & \multicolumn{2}{|c|}{$\begin{array}{l}\text { Annual } \\
\text { Collections }\end{array}$} & \multirow{2}{*}{$\begin{array}{l}\text { Actual } \\
\text { vs Target } \\
\text { Collection }\end{array}$} & \multirow{2}{*}{$\begin{array}{c}\text { Collection } \\
\text { vs due } \\
\text { Loan } \\
\qquad \%\end{array}$} \\
\hline & $\begin{array}{l}\text { TZS } \\
\text { (Bill) }\end{array}$ & $\begin{array}{l}\text { US } \\
\text { (Mill) }\end{array}$ & $\begin{array}{c}\mathrm{TZ} \\
\text { (Bill) }\end{array}$ & $\begin{array}{l}\text { USD } \\
\text { (Mill) }\end{array}$ & $\begin{array}{l}\text { TZS } \\
\text { (Bill) }\end{array}$ & $\begin{array}{l}\text { USD } \\
\text { (Mill) }\end{array}$ & & \\
\hline $2006 / 2007$ & 25.8 & 51.5 & 0.45 & 0.90 & 0.05 & 0.1 & $11.0 \%$ & 0.2 \\
\hline $2007 / 2008$ & 33.4 & 64 & 2.21 & 4.24 & 0.86 & 1.55 & $39.0 \%$ & 2.6 \\
\hline $2008 / 2009$ & 46.5 & 84 & 4.07 & 7.35 & 1.18 & 1.89 & $29.0 \%$ & 2.5 \\
\hline $2009 / 2010$ & 51.7 & 82.8 & 2.79 & 4.48 & 2.15 & 3.3 & $77.0 \%$ & 4.2 \\
\hline $2010 / 2011$ & 152.2 & 233.6 & 5.01 & 7.70 & 4.41 & 6.77 & $88.0 \%$ & 2.9 \\
\hline $2011 / 2012$ & 160.7 & 225.9 & 12.23 & 17.20 & 11.51 & 16.63 & $94.0 \%$ & 7.2 \\
\hline 2013 June & 222.1 & 299.7 & 18.00 & 24.30 & 14.85 & 43.04 & $83.0 \%$ & 6.7 \\
\hline $\begin{array}{l}\text { Cumulative/ } \\
\text { Average }\end{array}$ & & & & & 35.01 & 10.47 & $60.1 \%$ & 3.7 \\
\hline
\end{tabular}

Source: Field Survey 2013

Diminishing value of loans: Possibly due to political expediency, the Board disbursed interest-free loans from its inception until 2012, implying that the real value of the loans disbursed from 1994 to 2012 will never be recovered due to inflation. The introduction of an interest rate of 6 percent in 
20II/20I2 aimed to recover the loans in real terms, but this was below the inflation rate of 9.4 percent. In addition, the low success rate in tracing loans beneficiaries results in delayed repayments, which lowers the value of the recovered loans. To address this issue, the Board plans to introduce a value retention fee at a rate equal to or slightly higher than the annual inflation rate.

\section{Conclusions and Recommendations}

The challenges experienced by the HESLB are not unique. Similar challenges are encountered by student financing schemes in Kenya, Ghana, Mauritius and South Africa. Crosscutting issues include inadequate funding due to dependence on government and poor loan recovery rates, mainly due to the lack of strong loan recovery mechanisms and weak legal frameworks. Corruption has also been identified as one of the challenges confronting student financing schemes in Africa. However, among the loans schemes whose performance we have reviewed, Tanzania's HELSB performs very poorly. The following recommendations are proposed to build a strong and efficient student financing scheme in this country:

I. The Board should diversify its sources of funding by embarking on different income generation activities to reduce its dependence on the government. It should explore partnerships with potential financiers and investors in higher education such as banks and companies. This financing modality has worked in Mauritius and Kenya. In 2013, the HELB partnered with the Latimer Education Company based in the United States to increase its funding (Nganga, 2013). The Board also partners with Intra Health of Kenya to provide loans to students pursuing medical and health related qualifications. The HESLB could also consider borrowing from international banks such as the African Development Bank and the World Bank.

ii. In the worst case scenario, the HESLB should be disbanded and a Higher Education Student Loans Bank should be established using the public-private-partnership model. Students and their parents/ guarantors could borrow from this bank and be responsible for loan repayments. The idea of an education bank is not new in Africa. In I993, the Nigerian government disbanded the Nigerian Students Loans Board due to poor debt recovery and established the Nigerian Education Bank (Chuta, I998), which also failed to deliver. In 20I3, a Bill to reintroduce the Nigerian Education Bank was tabled in the House of Representatives and supported. This bank (which has not yet been established) would provide interest free loans to students in universities and other higher education institutions.

iii. Repayment of HESLB loans should be made mandatory through 
direct deductions by employers from loans beneficiaries' salaries as with income tax and social security funds. This would reduce the costs of tracing loan beneficiaries and improve the level of loan repayments. It would require the tightening of the legal framework to enable the HESLB to prosecute employers who fail to deduct loans from their employees' salaries and loan beneficiaries that default. Loan recovery could be further strengthened if the HESLB were to partner with the National Identification Authority or the national social security funds which would provide identification numbers to all loans applicants that could be used to track beneficiaries employed in the formal sector. This strategy has been employed by the HELB in Kenya. However, challenges remain in tracing loan beneficiaries employed in the informal sector or self-employed. For this category of beneficiaries, the Board should cooperate with Registrars of non-governmental organisations and companies and the Business Registrations and Licensing Agency (BRELA). These organisations work with the informal sector and could assist in tracing loans beneficiaries employed in that sector. Such cooperation would also need to be included in the HESLB's legal and policy frameworks.

iv. The Board should make effective use of guarantors and local leaders in tracing loan beneficiaries. Such individuals have vital information on beneficiaries' whereabouts and this system has been effectively used in Kenya.

v. Part IV clause 6 of the HESLB Act I7 of 2007 requires a loan beneficiary employed by a foreign government/company to arrange with the Board the amount and period during which remittance of funds shall be made. With government support, the Board could establish a loans section in every Tanzanian embassy that would deal with loan recoveries from beneficiaries employed abroad.

vi. Finally, aggressive public education and campaigns are required on the meaning and importance of student loans and loan repayment. This approach has been very successful in Ghana.

\section{References}

Ally, A. M., (20I5). Sustainability of higher education students' loan scheme (HESLS) in Tanzania. European Journal Business and Management, 7 (9), I49-163.

Athumani, R. (2016). New revelations on students'loan rip offemerge. Retrieved on August 8, 2016, from http://allafrica.com/stories/ 201606I60290. html

Atuahene, F. (2008). The challenges of financing higher education and the role of student loans scheme: An analysis of the Student Loans Trust 
Fund in Ghana. Higher Education Policy, 56, 407-42I.

Bangu, A. (2012, September). Total approach to financing higher education students' loans. Paper presented on the 4th Higher Education Forum, at Naura Springs Hotel, Arusha.

Collins, C. (20I3). An overview of higher education and development. In Wiseman, A.W., \&

Wolhuter, C.C. (Eds.) the development of higher education in Africa: Prospects and challenges (pp.2I-65) 21 International Perspectives on Education and Society. London: Emerald Group Publishing.

Chuta, E.J. (I998). New dimensions in educational financing: the Nigerian Education Bank. Higher Education Policy 35, 423-433.

Department of Higher Education \& Training. (20I2). Report of the ministerial committee on the review of the National Student Financial Aid Scheme. Retrieved from http://www.info.gov.za/view/ DownloadFileAction?id=II9245.

Felix, M. J. (2009). Evaluation of higher education financing in Tanzania: The case of higher education students loans board (HESLB) (Unpublished Master's dissertation). University of Dar-es-salaam, Dar-es-Salaam.

Higher Education Loans Board (HELB) (20I3). Strategic plan 2013-2018. Nairobi: HELB

Ishengoma, J. M. (2004). Cost-sharing in higher education in Tanzania: Fact or fiction? Journal of Higher Education in Africa, 2 (2), IOI-I33.

Ishengoma, J.M. (2006). Students' backgrounds, higher education costs and attitudes towards cost sharing in Tanzania. Case study of the University of Dar es Salaam and St. Augustine University of Tanzania. Research report submitted to the International Comparative Higher Education Finance and Accessibility Project, Center for Comparative and Global Studies in Education, SUNY, Buffalo.

Ishengoma, J.M. (2008, November). Financing public higher education in Tanzania: Towards a new model and implications for development and retention of the next generation of academics. Paper presented at University Leaders' Forum: Next Generation of Academics. Accra.

Mohadeb, P. (2006). Students' loans scheme in Mauritius: experience, analysis and scenarios. Paris: UNESCO, IIEP.

Mohadeb, P. (20IO). Mauritius. In P. Pillay (Ed.). Higher education financing in Eastern and Southern Africa (pp.8I-Io2). Cape Town: Center for Higher Education Transformation.

Ndomba, A.M. (2009). Effectiveness of higher education students' loans repayment process in Tanzania. (Unpublished master's dissertation), University of Dar es Salaam.

Nganga, G. (20I4 November). Student loan systems restructured across East Africa. World University News, Issue No. 296. 
NSFAS (National Student Financial Aid Scheme) (2009). NSFAS Ministerial review report.

Odebero, S. et al (2007). Equity in the distribution of HELB loans in Kenya in relation to students characteristics: An empirical analysis. Educational Research and Reviews 2(8), 209-2I9.

Onen, D. et al. (2013). Managing the student loans schemes in Africa: Lessons for young loan schemes. International Journal of Education and Research 2 (12), 27I-284.

Otieno, W. (2004). Student loans in Kenya: Past experiences, current hurdles, and opportunities for the future. Journal of Higher Education in Africa 2 (2), 75-99.

Owino, E. (2003). Financing higher education in Kenya: The case of student loans. (Unpublished Master thesis). Addis Ababa University, Addis Ababa.

Rugambuka, I. B. (2008). The performance of higher education students' loan scheme in Tanzania: The stakeholders' views. (Unpublished Master Thesis). University of Oslo, Oslo.

United Republic of Tanzania, (URT). (I999). National higher education policy. Dar-es-Salaam: Ministry of Higher Education Science and Technology.

Wangenge-Ouma, G. (20I2). Tuition fees and the challenge of making higher education a popular commodity in South Africa. Higher Education. doi: I0.1007/S10734-012-953I-6

Woodhall, M. (I99I). Student loans in higher education 3. English-speaking Africa (3). Paris: International Institute for Educational Planning.

World Bank. (2010). Financing higher education in Africa. Washington, D.C.: The World Bank

Yamane, T. (I967). Statistics: An introductory analysis (2 ${ }^{\text {nd }}$ Ed.). New York: Harper \& Row. 